\title{
MULTILINGUALISM AND MULTICULTURALISM: CHALLENGES FOR EDUCATION AND SOCIALIZATION IN THE XXI CENTURY
}

https://doi.org/10.37096/SHDISJ-20-2.2-0001

\author{
Boski Pawel \\ ORCID ID: 0000-0003-0984-5686 \\ Kmiotek Lukasz K. \\ ORCID ID: 0000-0002-5726-1274
}

Shatruk Yulianna

\begin{abstract}
Our paper has two goals. First we review the state of multilingualism in the world today, with a particular emphasis on Europe which was the cradle of foreign education many centuries ago and has remained the leader in this field. There is no doubt that biand multi-lingualism characterize successful people of the XXI century, while the confinement to one language can be seen as a personal and social handicap or a socialization problem.

We argue next, that the growing bilingual potential should be analyzed as integral part of bicultural personality of our time. Whether we speak native or second language, we participate in cultural communication. Language is not just a multilevel linguistic structure but also part and parcel of its culture, the warehouse of its meanings and history. Learning a language one acquires its culture. In this context we set research questions pertaining to the language $\leftrightarrow$ cultural values and identity mutuality: Which and under what conditions impacts the other?

Two studies were conducted by the second author on Polish-French bilingualism and bicultural identity of Romanesque university students and immigrants of two generations in France and Belgium. Opposite to our hypotheses, there was no evidence for mutual reinforcement of linguistic proficiency and cultural identity. French language skills among Romanesque students were low but their idealistic French identity was high. Polish cultural identity was dominant, over French, among second generation immigrant youths. We explain these results referring to theories of idealized identity and nostalgia.

We conclude with recommendations, that second language teaching should not only be intertwined with general culture learning but also should convey realistic and not idealized versions of other cultural worlds. Extending learner's identity, rather than replacing one by the other should be the goal of bilingual education.

Keywords: socialization, education, multiculturalism, multilingualism, values, cultural symbols.

\section{Introduction}

In our paper we start with painting an image of bi- and multilingualism in contemporary world, but with the focus on Europe, which was the cradle and remains the champion in foreign

languages education. As cultural psychologists, we do not regard language separate from culture in which it is embedded. To the opposite, language serves various purposes of cultural communication and it is the library or a
\end{abstract}


warehouse of cultural deposits: meanings and history. When you learn a language, your native or foreign, you become a member of its culture. This phrase could indeed serve as a motto of our work. We consider these two features: linguistic proficiency and cultural identity as mutually intertwined or co-determined. Our research reported in the second half of this paper is based on these premises.

The article aims to argue that bi/multilingualism and biculturalism become a challenge for the educational system in the twenty-first century, and one of its tasks of top importance. It is a new phenomenon, because traditionally, socialization was considered as a process, parallel to schooling, whereby children and youths were acquiring the desired qualities for future adult citizens of their society. That society was, as a norm, considered as unilingual and unicultural. These assumptions are not true anymore.

To illustrate our central thesis, that language is embedded into its culture and must be studied jointly, we shall exploit two examples of memes. Memes have become very popular in popular culture and they are concise, shorthand pictorial records of current themes mixed with historical references. The two memes are seen on exhibits 1 and 2 .

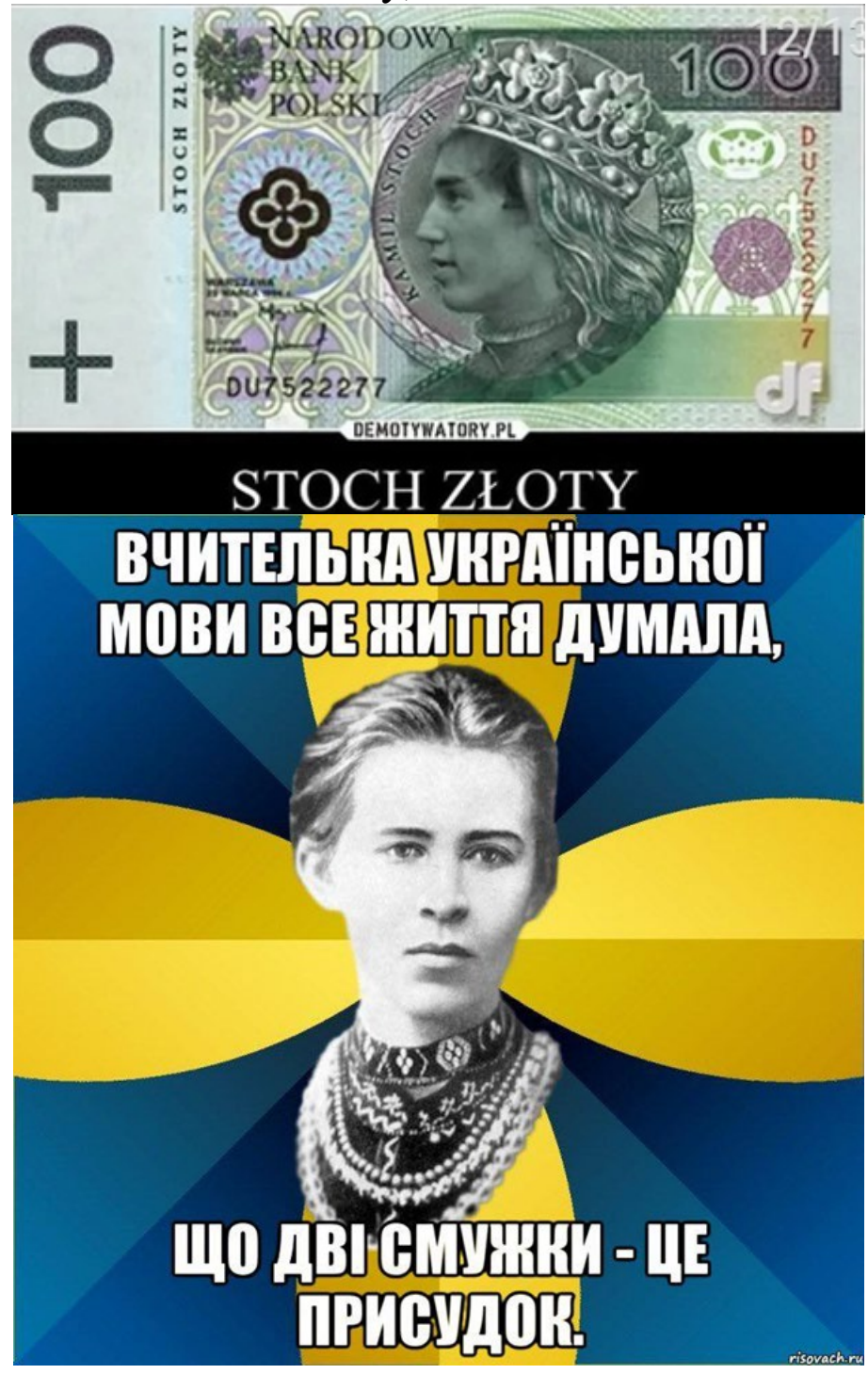

Exhibit \#1. Kamil Stoch - a Polish meme.

Exhibit \#2. Lesia - a Ukrainian meme. 
Meme \#1 exploits the popularity of Polish ski-jump champion, Kamil Stoch. His profile is a morph appearing on a note of 100 PLN, substituting king Władysław Jagiełlo of XV century. The note of 100 in Polish is STO ZŁOTYCH. When "CH" is cut and moved to STO, then it becomes Kamil's last name: STOCH. There are only two words in this meme but still it is culturally very rich. Knowing the meaning of the two words is not sufficient to understand the hidden name of the meme.

Meme \#2 has come from Ukraine. Since it is written in Cyrillic script, many readers will not understand this. But even if you read: "The teacher of Ukrainian used to think all her life that two strips indicate a predicate". Indeed, these two strips indicate a positive pregnancy test. Moreover, the teacher is a famous young Ukrainian woman Lesia, a poet and patriot, who laid important merits for the renaissance of Ukrainian language. Again, this meme is every rich in cultural connotations and mere understanding of few words would not help to get to this deeper meaning.

\section{Theoretical background}

Foreign languages in the history of European culture. Unlike in other continents, Europe has a long tradition of bilingualism. In past centuries it was limited to the slim layer of educated and socially privileged strata, as a marker of their high status. In medieval times Latin was this second language which served the clergy, medical doctors and layers. Until quite recently Latin was compulsory at high school level; then, students in the three professions learned Latin at university and then used Latin terminology, even if in diminishing scope, in work practice.
Gradually Latin was replaced with French culture and language which dominated in the European landscape throughout the eighteenth and nineteenth centuries. This was the case in many countries, only in Poland oriented towards the West and Napoleon, but also in Russia, which opposed military against the Napoleon. For nobles and intelligentsia of that time, French represented high social status. It was used for reading books and conducting dignified conversation. But apart of this haute culture, linguistic situation in the world was diversified. Colonization split the continents in territories where several European languages dominated: French, English, Spanish, and Portuguese. Those languages became official stamps of colonial powers and vehicles for local elites to gain status and influence. The appropriation of a language of conquerors became a springboard for social promotion.

Russian language too, can be seen in historical perspective as a language of colonizers not only in large parts of Asia, but also in Europe. Our country, Poland, vanished throughout the whole XIX century from the map of Europe, being partitioned between three neighboring states. The conquerors brought their languages, and Poles became subjects of russification and germanization. Much more than with the off Europe colonization by Western powers, German and Russian were perceived as languages of the invaders and the attempts of their forceful inculcation were met with resistance. The resistance to russification (or sovietization) meant that the generation of Poles born shortly after World War II, for whom learning Russian was compulsory at least for seven years at school, has acquired only basic skills in 
this language, so similar to the mother language. The cohorts of 40-years old Poles or younger are illiterate in Cyrillic script.

The era of French as popular second language lasted well into the second half of XX century, when it ended and was replaced by the dominance of English. With English we have, for the first time in history, a phenomenon of dominance at a truly global level. In all domains of international relations (science, sports, politics, business, popular culture), English has become a language of communication. Practical proficiency in English has become a necessary condition for success in life. English may be prestigious and fancy but its role is mainly utilitarian.

These historical observations have important theoretical consequences. Second language is not a neutral subject of education, driven only by individual learner's interests. Language may be culturally attractive and prestigious, or may well be an object of political hatred, generalized from the feelings cherished for the country and culture it represents. When a mother languade form into a core value of identity (see: Hamers \& Blanc, 2000, p. 202; Smolicz, 1981), and the L2 is the language of the invaders, then even constitutional changes and modern teaching methods are unsuccessful to overcome the resistance towards bilingualism. Positive motivation to learn, or negative motivation not to learn, are important psychological phenomena operating at a larger social scale.

\section{Bi- / multilingualism in Europe and} the policy of the European Union. In modern times, a significant part of the world's population acquires at least two languages beginning in childhood (Crystal, 2003; Mohanty \& Perregaux, 1997; Schönpflug, 2008). While perfectly balanced bilinguality is still rare, fractional profiles of unequal competences abound. They are not reported in macro-level statistical reports but still, these reports give us orientation about the scale of bi- /multi-lingual phenomena.

There are 24 official languages of the members states in the EU. As early as 1995, the European Commission (EC) published a so-called a white paper which announced that trilingualism should be an official goal of European education systems. This policy was further advanced by EC in the document "New approach to educational strategy". This goal was reformulated at the Barcelona conference in 2002 as part of the $1+2$ directive. It meant that all European citizens should be encouraged to learn two additional languages in addition to their 'mother language' as part of compulsory education. This policy obviously contributes to reducing the cultural distance between the members of the community and thus to strengthen the integration process.

Also the role of Socrates / Erasmus program should not be underestimated in this endeavor. It enables the exchange of students between partnership universities. Figure 1 shows how this EU policy idea is reflected in foreign language competences in members states. 


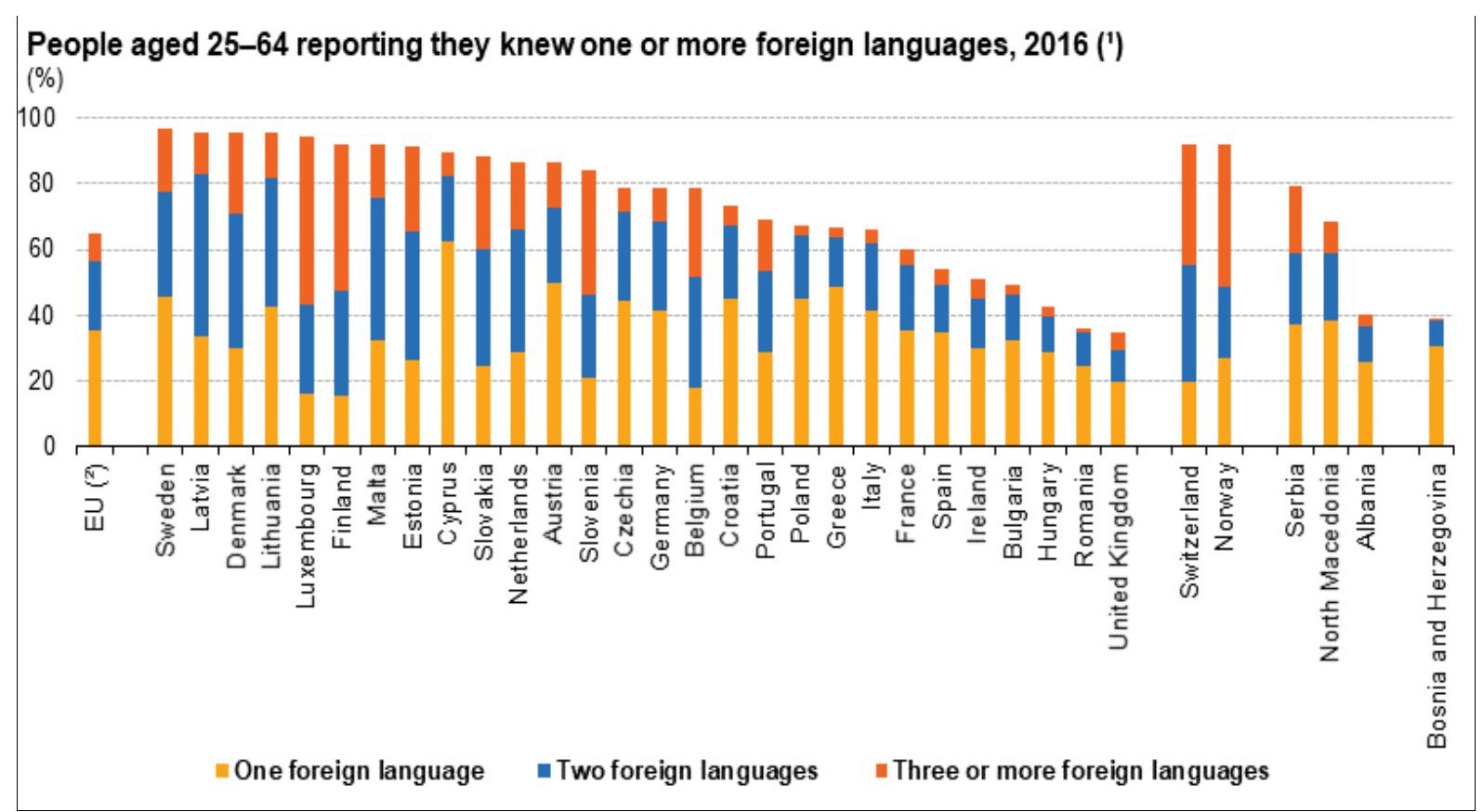

Figure 1. Multilingualism in Europe

In general, in more than half of European countries, $80 \%$ of citizens declare competence in 1 to 3 foreign languages; and for the whole population of the EU this rate is about $70 \%$.

In small, less populated countries, the proliferation of foreign language skills is better. The top polyglot are Scandinavian countries and those which are small and less populous. recorded in Scandinavian countries and - for different historical reason of connection with Soviet Union/Russia - the Baltic republics (Lithuania, Latvia, Estonia). Some European countries have more than one official language (Belgium, Luxembourg, Switzerland), which also helps in formatting multilingualism of their populations. The five most populous countries (Germany, France, UK, Italy, and Spain) have the lowest rates. It also happens, that their three mother languages, English, French, and Spanish belong to the class of world spoken languages. On the whole, the case of United Kingdom, the country which left the Union, is much telling: in 2016, 65\% of their citizens declared no knowledge of any foreign language (if naturalized people were excluded this proportion would definitely be higher). The conclusion we draw from this is clear: there is no need to learn foreign languages, when your native is a global one, others will learn yours to speak with you.

While $64.6 \%$ of the EU people of working age (25-65) declared at least one foreign language, almost a quarter $(24.8 \%)$ of population asserted that they knew this language (their best known foreign language) at the fluency level (which was defined as: "I understand a wide range of demanding texts; I speak flexibly a foreign language. I am convinced that I have mastered the language almost completely").

Other studies draw similar conclusions. Bilingualism is becoming more common in the modern world (Delvin, 2015; Lapresta-Rey \& Huguet, 2019). Presently, most of world population is bilingual or multilingual instead of monolingual (Crystal, 2003; 
Grosjean, 2010). The point is however, of how general is this trend and which are the exceptions.

It is meaningful to compare in this context the European situation on bi/multilingualism with that of the US. After all, the concept of Western civilization encompasses countries on both sides of the Atlantic. As figure 3 shows, the difference could hardly be larger: 92\% of young European learners are contrasted with $20 \%$ Americans who get some of second language experience but only at a basic level.

\section{Europe drastically outpaces U.S. in foreign language learning}

\%o of primary and secondary students learning a foreign language in Europe (2016) and the U.S. (2017)

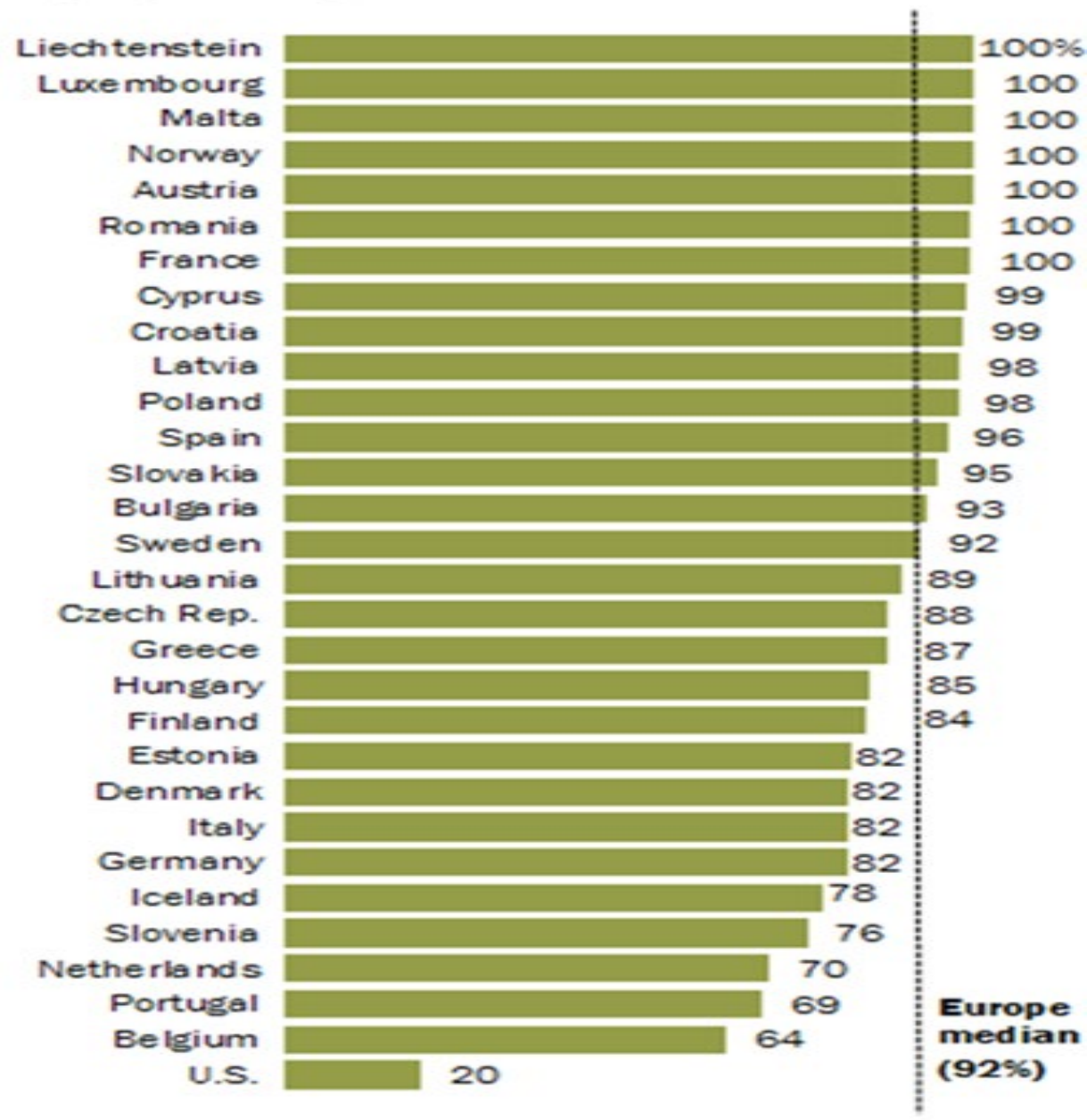

Note: Data not aveilable for the UK, Irelandor the Republic of Macedonia. US. includes 50 states and the District of Columbia. Source: Europe date from Eurostat, accessed June 20, 2018. U.S. date from -The National K-12 Foreign Language Enrollment Survey Report, " American Councils for Intemetional Education, June 2017.

PEW RESEARCH CENTER

Figure 2. Percentages of primary and secondary students learning aforeign language in Europe and in the US.

Thus, the United States stands off from the typical image of a bilingual country. Here, only immigrants are bilingual. Citizens born at place speak only English: They do not have to or want to be bilingual, and there has always been reluctance by official factors (Aída Hurtado, 2016; Aida Hurtado \& Gurin, 1987). In short, Americans remain monolingual and continue that policy 
based on unscientific and totally false beliefs that bilingualism leads to mental retardation. In fact acquiring English (or any second language) promotes human development around the world, as much as staying with English only is a hindrance for development for Americans and other Anglophones.

What is particularly important, is that the trend towards multilingualism in Europe is growing when we observe younger cohorts entering adulthood; see figure 3.

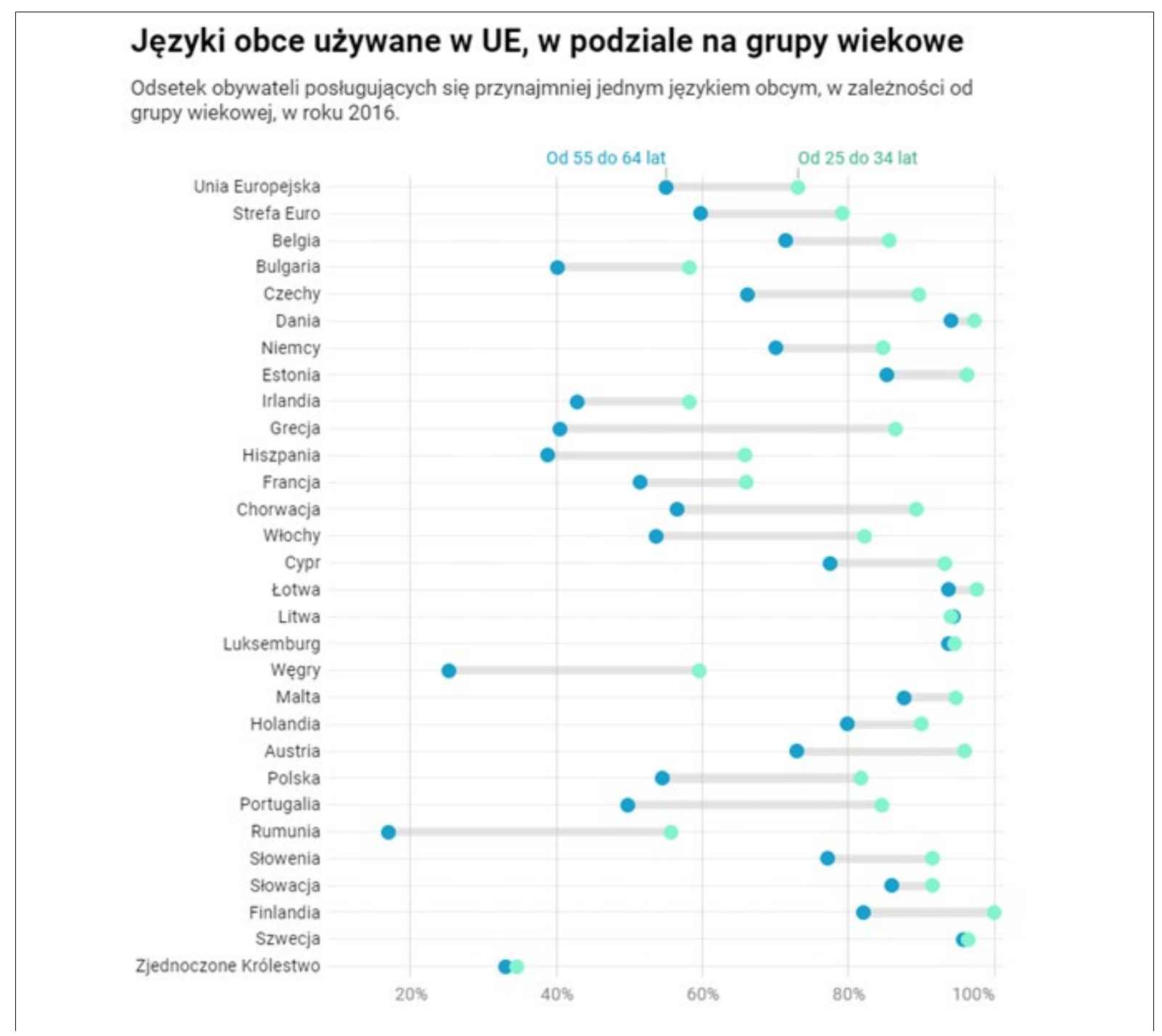

Figure 3. Biligualism in two cohorts of Europeans

In the life-span of one generation, the percentage of Europeans mastering at least one foreign language grew up by $20 \%$. There exist large between country differences too. In the top raking Sweden and the lowest United Kingdom, no cohort differences have been observed.
The association of British monolingualism with the Brexit must be emphasized. Even that some countries are close to the ceiling effect of bilingualism, the process will continue. This conclusion is well justified when we observe educational requirements regarding 
foreign languages across the continent; see figure 4.

\section{Most Students in Europe Must Study Their First Foreign Language by Age 9 and a Second Foreign Language Later}

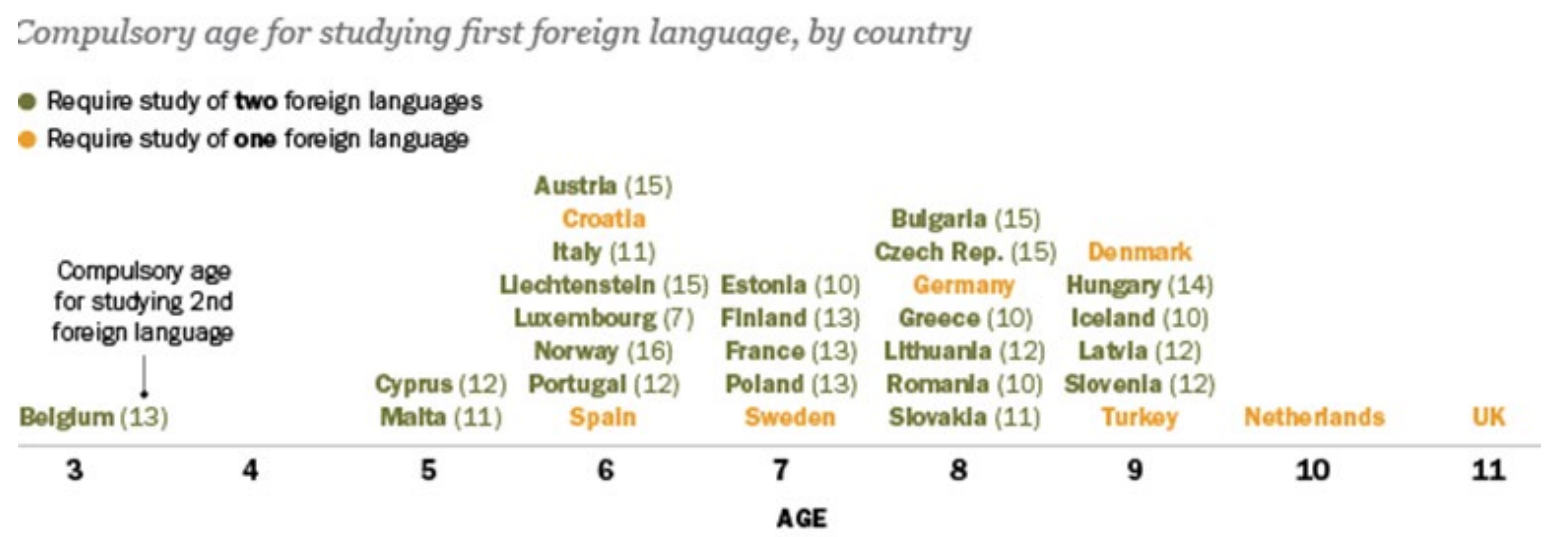

Vote: Pupils in Scotland (a part of the UK) and Ireland are not required to study a foreign language. The German-speaking Zommunity in Belgium studies their first foreign language at age 3 and a second at 13; the Flemish Community does so at ages 10 and 12; and the French Community begins their first foreign language at age 8 or age 10 and are not required to itudy a second foreign language. In Estonia, pupils must study a second foreign language between ages 10 and 12 . In inland, pupils must start learning a foreign language between ages 7 and 9; in Sweden, between ages 7 and 10. Source: Eurostat

Figure 4. Compulsory age for studying first foreign language, by country

Consensual to the EU Commission recommendations, majority of member states have implemented the policy of two foreign languages instruction. The mean age for teaching the first foreign language (which is English) coincides with the beginning of schooling, which is the age of 7; second language instruction starts on average at 13 .

Still, some variability occurs. Within the German-speaking community of Belgium, for example, foreign language education begins in the third year of life, while in parts of Great Britain (except Scotland) in 11 years of age. On the other hand, the legislation of Scotland and Ireland does not oblige their nationals to learn a foreign language. However, students apart from English also learn Gaelic. The Scottish language learning policy implies that the curriculum offers optional foreign language learning for students between 10 and 18 years of age. Nowadays in Poland, pupils often start learning English in kindergartens (thus at the age of 4-5). The former privilege of higher social class to speak a second language on a daily basis becomes more and more ubiquitous.

The young generation acquires foreign languages more intensively than ever before at school. It is also due to the technical progress. This phenomenon will certainly lead to a significant increase in the multilingualism of Europeans over the next 15 years.

English around the world. It goes without saying that presently English is a lingua franca in the world of today (Crystal, 2003). Figure 5 presents statistics concerning self-assessment of the proficiency of this language among Europeans. 


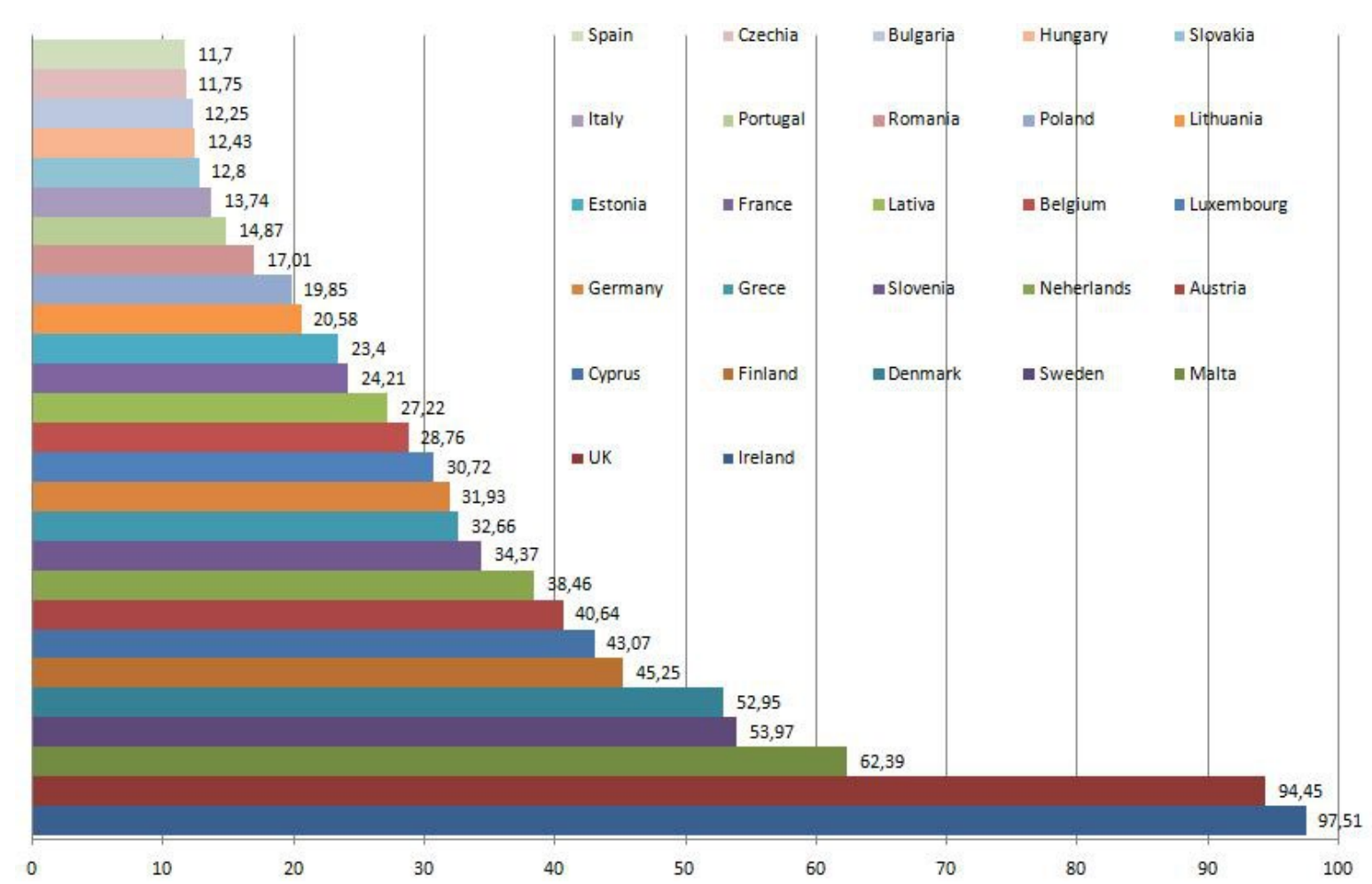

Figure 5. Proficiency in English among Europeans

English is spoken by over half of Scandinavians, but only $12 \%$ of Spaniards. English is the most widely learned foreign language in almost all European countries and at all levels of education. $73 \%$ of primary school students in Europe and more than nine out of ten students in secondary education studied English at school in 2009-2010. In Poland, of which we are most familiar with, the situation is similar; at primary level, $96 \%$ of all pupils learned English; followed by $34.4 \%$ German; $3.6 \%$ Russian; 2.9\% Spanish; 2.3\% French as second foreign languages.

\section{Conditions} to

foster multilingualism. Content and Language Integrated Learning (CLIL). Bilingual education in European countries is most often based on the CLIL program. In CLIL programs, the target language (i.e.: English, French) is used only to a limited extent, to a limited number of school subjects (usually only one or two).
Therefore, in terms of the teaching objectives (acquiring the knowledge taught through the target language) and time allocated to its daily use, CLIL seems to be less beneficial than full bilingual education, e.g. compared to immersion programs leading to additive bilingualism (Hamers \& Blanc, 2000). The CLIL model has become the dominant model of bilingual education in Europe and has been incorporated into the public education system (Cenoz et al., 2013). The aim of this model is mainly to develop more effective approaches to foreign language teaching by increasing: (i) exposure to the target language, (ii) communicative practice through the integrated learning of content and language as their means of communication. The European Commission promotes the teaching of foreign languages to improve individual mobility and European integration. 
Immersion programs. Outside Europe Canada has been officially a bilingual country at the federal level since 1971, after 100 years of Anglo-French antagonism. Canada's case testify that the outset of the multiculturalism coincided with the effective defense of the French language in the province of Québec. At the same time, Québec represents the highest (comparing to other Canadian provinces) level of bilingualism in the country. For education purposes, immersive method was applied to teach the second language, primarily French among Anglophones. The conditions for immersion with L1 in L2 are the following: the child learns from home L1, which is the language of the majority and has high social status; instructors and the school administration uphold this status; the child himself values his L1; the child, and the environment around him (school and parents) are interested in acquiring skills in L2 (see also Kurcz, 2005). Immersion is that the first two (three) years of study take place in L1, then a pupil move on to study two languages (one subject in L1, another in L2), with each subject changing from year to year (Lambert, Genesee, Holobow, and Chartrand, 1993).

Despite of great enthusiasm which accompanied Canadian immersion programs, their results of are suboptimal. According to the 2016 census, $44.5 \%$ of tiehe Francophone Quebec's population is bilingual; in the remaining provinces, this rate is only $7.5 \%$. In short, Canadian bilingualism policy does not work, apart of Quebec, which is destined to be francoanglo for simple survival, the rest of that huge country is not linguistically different from the US.

\section{Multilingual}

macro-level environment. We miss relevant research data on Africa but likely it is the most multilingual continent. In a country like Nigeria with about 240 ethno-linguistic groups of at 100,000 large communities, speaking three languages appears as a norm. There, English is the official language of the country; Hausa, Ibo and Yoruba are the largest national languages, and for most other individuals an ethnic language of a local community often is the mother language. Those languages are used not for all functions; some of them are spoken but not written (but the Bible is translated to all, where Christianity is professed). If anything, the richness of linguistic variability in Africa will be shrinking in the future.

Back to Europe, Ukraine offers a good example of a thriving multilingual environment. Two Slavic languages: Russian and Ukrainian are used on daily basis. The political context of this is obvious so feel exempted from further analysis. Since Poland is the second important neighbor with a long historical ties of living in one state, and current economic migration, and student migration, Polish is likely to become a third language. Ukrainians often study in English at Polish universities, and so they become four language individuals.

$$
\text { Multilingual micro level }
$$

environment. With the global opening human migration contacts have been intensified to the level unheard before. Migrants and their children carry an acculturation potential which facilitates their bilingualism. Mixed marriages, travelling and settling down in a third country, further contribute to these phenomena, resulting in multilingual, 
multicultural lives of more and more numerous individuals. Thus, with conducive conditions of life in a multilingual environment and by often changing the place of residence, it is possible to develop a truly multilingualmulticultural mind. The secret of this is a culturally rich and changeable environment. Just as a living in a secluded, walled-off environment is a secret of producing a monolingualmonocultural life.

Benefits of being bilingual and bicultural. When intentional effort has been present in Europe for centuries to include bilingualism as an essential part of school education, the question of benefits of such learning seems to be ill addressed or irrelevant: intellectual elites would not err for such long period of time. The purpose of all this was to ascertain that new generations will be formed with "broader horizons", and a "better understanding" of their world. But contemporary psychology wants to obtain precise knowledge what are the consequences of these educational efforts.

It was repeatedly shown that the bilingual brain has better cognitive control than the monolingual brain (Bialystok, 1999, 2011). This improvement concerns the ability to switch between different tasks. This advantage is believed to be due to the enhanced ability to inhibit one language while in use of another (Emmorey et al., 2008).

Positive effects of bilinguality concerns both oppositional ends of the age spectrum: it has been found that seven months old children raised by parents with different mother languages adapted better than monolingual to environmental changes. In bilingual seniors bilingualism delays the effects of neurodegenerative diseases of the nervous system, delay cognitive decline and the outset of dementia (Bialystok, 1999, 2011).

It is important, that the beneficial effects of bilingualism are difficult to disentangle from biculturalism, to which it is subsumed. To discuss such effects as cognitive flexibility, creativity, complexity, tolerance, and openness to diversity, it is necessary to broaden the scope of our theoretical analysis.

Frame switching as a mechanism of negotiating bicultural identity. In his pioneering works Hong et al. (2000) coined the concept of cultural frame switching (CFS) mechanism. It enables a bilingual/bicultural individual to switch between cognitive styles: analytical vs. holistic. Boski (2008) extended these arguments to axiological domains of two bilingual groups: Polish-Americans and Arab-French Tunisians. Depending on language they use (are tested in), bilinguals emphasize values of one culture or another.

Tadmor and colleagues (Tadmor et al., 2012; Tadmor et al., 2012) advanced the argument that multicultural experience has significant positive effect in decreasing a need for cognitive closure and in increasing integrative complexity. These two processes form the basis of two mechanisms (a) weakening prejudices and stereotyping towards outgroups; and (b) enhancing creativity and improving ability to implement innovations at work, which lead to professional successes. Individual subjected to experimental or life openness to cultural diversity cope better with the social and cognitive complexity of the world.

Possible problems? It is well known that bilinguals of the past intentionally used Latin proverbs or expressions (e.g. 
alea iacta est, pacta sunt servanda, etc.); or French (e.g. qui vivra verra, Paris vaut la messe, etc.). It was a sign of high culture. Nonintentional is mixing two languages, particularly adding words of L2 to L1 grammar structures (e.g. mam problem $z$ wypetmieniem income tax reportów $=$ I have some problems with filling out income tax report). This is when the two systems are activated and competing for expression; speaker may miss some words in his L1. Word competing (substitution) may also extend reaction times in bilingual experiments (Boski, 2021, ch.13).

More light on biculturals' identity problems is shed light by Benet-Martinez (Benet-Martínez et al., 2002; BenetMartínez \& Haritatos, 2005; BenetMartínez \& Hong, 2014). The author devised the concept of bicultural identity integration (BII) which reflects different forms that psychological biculturalism can take. Benet-Martinez contrasts

\section{Methodology}

Psycholinguists (Hamers \& Blanc, 2000; Wierzbicka, 1997, 1999) assert that the use of a given language is closely related to one's personal and cultural identity, national pride, personal convictions and attitudes - all of which influence the process of language acquisition. This theoretical psycholinguistic approach stresses that second language acquisition (not unlike first language acquisition) involves stepping into and merging with another culture, rather than simply acquiring a new linguistic code. In other words, to use a (second) language means to "become" a member of a certain ethnic or national group. This process involves taking part in various social interactions, and often results in one's own identity being harmonious vs. conflicting, but also unified (blended) vs. divided (compartmentalized) identity. The conflicting bicultural identity unveils possible tensions, difficulties and costs of negotiating bicultural identity. A young individual raised in such a complex environment requires extended attention and support in solving questions of belongingness (identification with reference group) at the interface of two cultures that should constitute his comfort zone.

We shall address some costs of bicultural and bilingual individuals in the studies conducted by Kmiotek (2020).

Our recent studies deal with Biligualism and Bicultural Identity. So far our paper discusses mainly the issues of bilingualism, but biculturalism has been introduced later. Our assumption, shared with other authors, is that the two features are tightly interconnected.

enriched, newly-defined and changed (Boski, 2006, 2021). Therefore, in the psyche of a bilingual a bicultural identity is formed (Grosjean, 2015; La Fromboise et al., 1993). This view implies that each language carries a specific cultural role that the speaker must take on, involving specific ways of thinking, norms of behavior, ways to express feelings. Thus, one of the fundamental aim of educational system is, through socialization process, to create favorable conditions for the development of bi/multicultural psyche.

The reason of their interconnectedness at the level of individual psyche is that language and other layers form the circle of objective culture; see figure 6 (based on Boski, 2021, ch.13). 


\section{Three layers of culture used in acculturation theory and research}

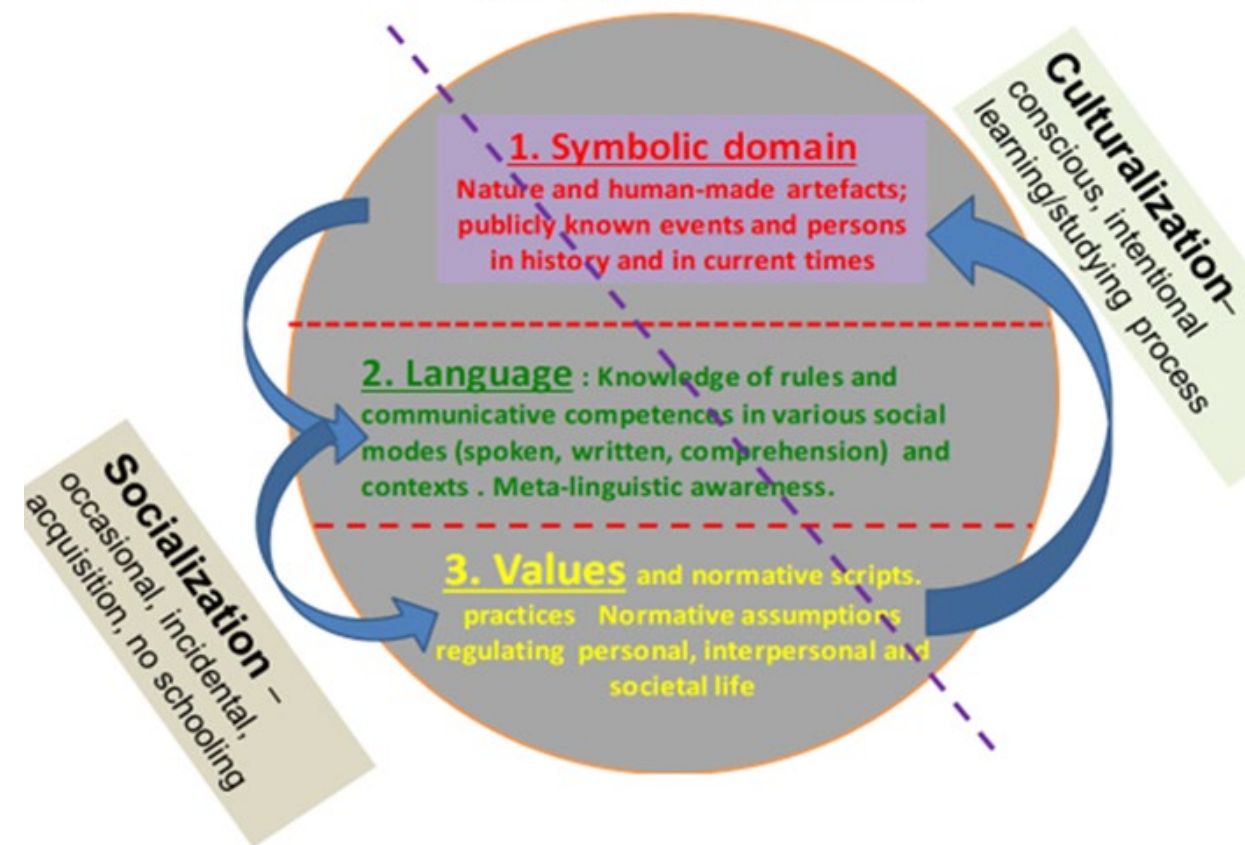

Figure 6. Three layers of objective culture and of individual cultural competences

Individuals functioning as members of any culture are programmed by its three layers: language - symbols - values / practices. The three layers are interconnected but maintain relative autonomy. When a second culture has been learned/acquired, the same three components form the process of acculturation, and eventually make up a bicultural individual. The diameter cutting the circle separates two processes occurring at culture learning. They are: (i) culturalization to cover intentional culture learning at formal schooling, and (ii) socialization which refers to incidental acquisition at home family and other social contacts.

Of the three layers, symbols may deserve more explication than the other two. They are nature-shaped or humanmade artifacts, events, and personage figures of history and of current public life, considered as important for cultural identity. Their representations are mainly pictorial, inculcated at school culturalization. Values and practices, on the other hand, are not subject of school learning but acquired mainly via socialization ("you should learn how to behave at home, not in school" - teachers often say). The different proportions of culturalization vs. socialization at the three layers are illustrated by the diameter slicing across them.

Cultural identity may apply to all three culture layers, but in its conventional use, it is covered by the symbolic and value aspects, leaving language apart. The concepts of biculturalism and bilingualism are used in a similar manner, respectively.

In Kmiotek's dissertation, the author was interested in studying the mutual relations of bilingualism and bicultural identity among five groups of participants immersed in Polish - French acculturation context. The research problem sought to answer whether higher linguistic proficiency corresponded with higher identity in joint cultural domain. Those participants were students of French language and culture at two Polish 
universities, $2^{\text {nd }}$ generation youths from high schools in Lyon (France) and Brussels (Belgium), and first generation Polish economic immigrants in Lyon.

They were tested with two types of linguistic tasks: (i) Polish $\leftrightarrow$ French bidirectional translations, and (ii) Polish and French auditory comprehension. To measure cultural identity a value inventory by Boski (2021/21) was used. Participants attributed each value (e.g. Maintaining close, long-term friendships; or Free love relationship, without a formal marital commitment) to one of four cultural cells in a $2(\mathrm{PL}: \mathrm{Y} \mid \mathrm{N}) * 2$ (FR: $\mathrm{Y} \mid \mathrm{N})$ matrix: $\mathrm{PL} * \mathrm{FR} ; \mathrm{PL} * \sim \mathrm{FR} ; \sim \mathrm{PL} *$
$\mathrm{FR}$; and $\sim \mathrm{PL} * \sim \mathrm{FR}$. Then, they endorsed personal preferences for each value (e.g. I maintain close, long-term friendships; or I favor a free love relationship, without a formal marital commitment); a rating scale ranging from -2 to +2 was used for that purpose. Identity index for each culture was a sum of products of culture value attribution and personal preferences (more on that in Boski, Kmiotek, 2021).

\section{Results}

Bilingual auditory comprehension was compared in five categories of participants and the findings are illustrated on figure 7 .

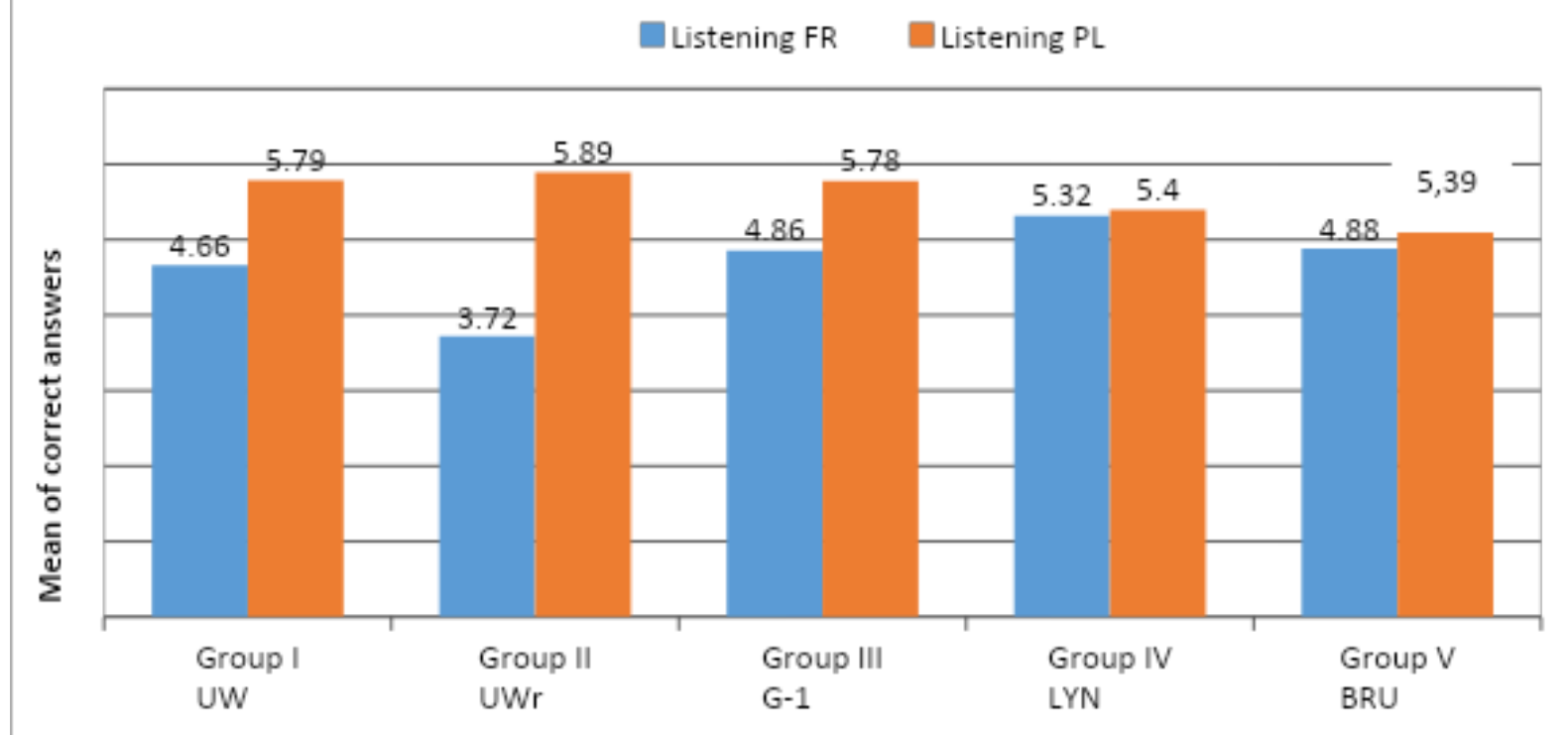

Figure 7. French and Polish auditory comprehension in five groups of participants

The main effect for language was highly significant, $\mathrm{F}(1,227)=54.06 ; \mathrm{p}$ $<0.001, \eta 2=0.19$ indicating that study participants were more proficient in Polish than in French. Significant interaction effect $[\mathrm{F}(3,227)=15.31 ; \mathrm{p}$ $<0.001, \eta 2=0.17]$ further indicates that Polish linguistic proficiency was not differ among the five categories of participants, but French proficiency was.
This difference reflects the poorer knowledge of their second language by university students in Poland.; consequently, Polish was their dominant language whereas participants residing in France revealed a balanced pattern of bilingualism. Results for the value-based identity ran the opposite direction; see figure 8 . 


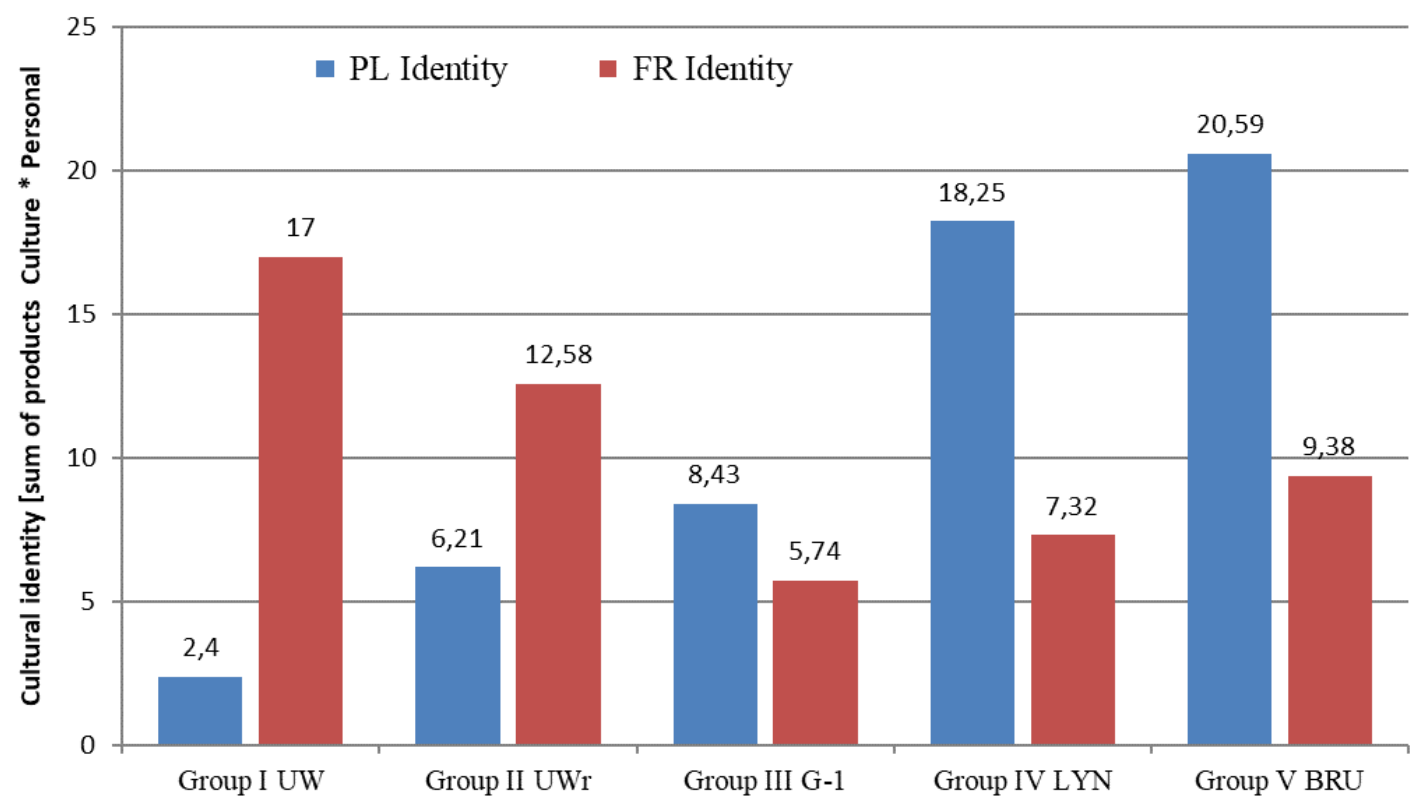

Fig.8. Polish and French identities in five groups of participants.

Notes:

UW = University of Warsaw students of French Language and Culture

$\mathrm{UWr}=$ University of Wrocław students of French Language and Culture

G-1 = Polish economic migrants in France (lyon)

$\mathrm{LYN}=2^{\text {nd }}$ generation Polish youths, international high school students in Lyon (France)

$\mathrm{BRU}=2^{\text {nd }}$ generation Polish youths, students at Polish high school in Brussels (Belgium)

Rather unexpectedly, it was high the home vs. Host country variable as a French identity which

characterized university students in Poland, while Polish identity dominated among second generation of emigrants in France and Belgium. The interaction effect $F(4,323)=14,75 p<0,001 \eta 2=$ , 15 testifies to these striking differences.

Thus, we observe a complementary rather than a mutually reinforcing phenomenon in bilingualism and bicultural identity. This led us to consider moderator in the analysis between bilingualism and bicultural identity. Such moderation analysis was performed (with the use of Macro PROCESS, Hayes, 2018, model 1). The predictor was the standardized indicator of bilingual proficiency; acculturation context of Poles living in Poland or Poles on emigration was the moderato; and FrenchPolish identity integration index was the dependent variable. 


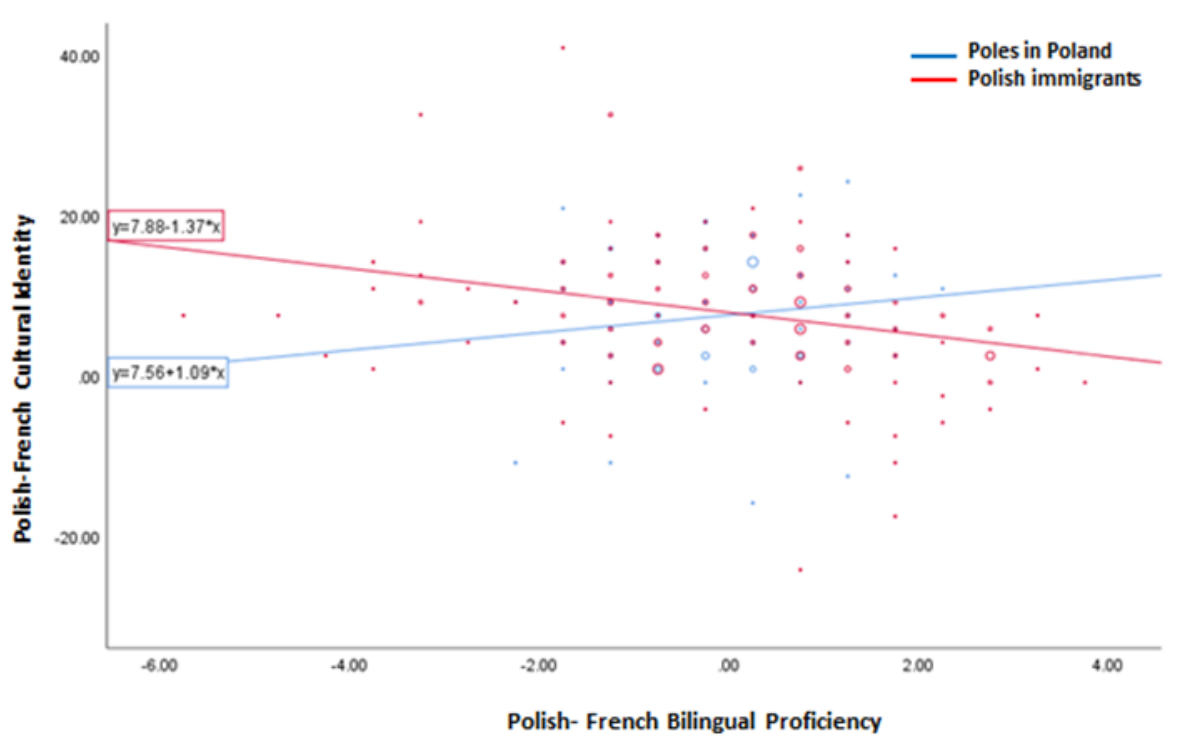
contexts

Figure 9. Bilingual proficiency and bicultural identity in two acculturation

The regression model fits the data $\mathrm{F}$ $(2,228)=3,91 ; p<0,05$. The main effect of bilingualism was also significant as indicated above (beta $=-0,18 ; \mathrm{t}=-2,78 \mathrm{p}$ $<0,01)$; but the acculturative context was not. An interaction effect between an acculturative context and bilingualism was significant $\mathrm{F}(3,227)=4,96, \mathrm{p}=$ 0,$002 ;$ beta $=-2,46 ; p=0,009$. The interactive component improved the percentage of explained variance of the dependent variable by $3 \%$. An analysis of bilingualism separately for two acculturative contexts indicated that for university students this relation was positive but statistically insignificant (beta $=0,15 ; \mathrm{t}=1,33 ; \mathrm{p}>0,05$ ); in emigration, this relation had an opposite direction and was significant: beta $=-$ 0,$28 ; \mathrm{t}=-3,54 ; \mathrm{p}<0,001$.

In Poland, increase of bilingualism (better French), goes hand in hand with an increase of integrated $\{\mathrm{PL}$ and $\mathrm{FR}\}$ identity; on emigration (in France and Belgium) - we observed an opposite trend, where improved bilingual skills diminish integrated identity.

For the group of Romanesque students at University of Warsaw we ran another analysis, which included Benet Martinez's BII measures (exemplary conflict items: I feel torn between Polish and French cultures; I feel that my two cultures, French and Polish contradict each other). We wanted to find out if the extremely high French identity of these people, and low Polish identity $\left[M_{F}=17.00>M_{P}=2.46 ; \mathrm{F}(1,95)=39.43 p\right.$ $\left.<0.001, \eta^{2}=0.29\right]$ generate a conflict in them, and how it is moderated by French linguistic proficiency.

In regression analysis, the aggregated French identity was found a negative predictor of the BII conflict ( $\beta=$ $-.26, \mathrm{p}<.01)$. Not intuitively, though, it was the lower and not higher French identity component which led to a more conflicting BII. To check if French proficiency added to this relationship, a moderation analysis was conducted using Macro PROCESS (Hayes, 2018, model 
\#1). French identity was set as predictor while French language proficiency (auditory) served as a moderator. Results are seen on figure 10 .

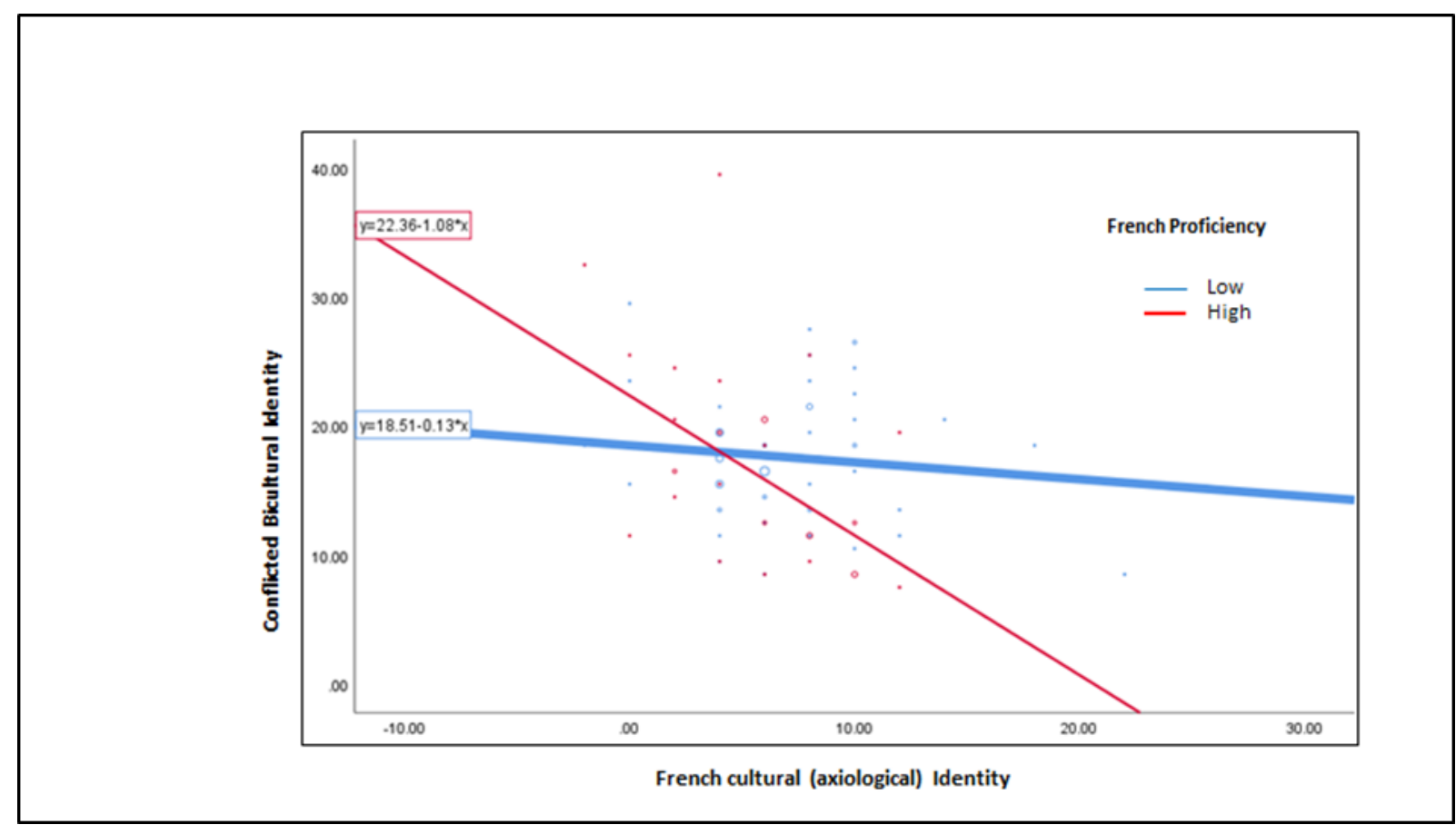

Figure 10. French identity and linguistic proficiency on bicultural identity integration index (conflict-harmony)

As the predictor and moderator enter a significant interaction $\left[\mathrm{R}_{\mathrm{ch}}=.084, \mathrm{~F}\right.$ $(1,90)=8.95, \mathrm{p}<, 01]$, the stronger partial French identity diminishes conflicting BII but only for those students who were of more advanced French proficiency $(\mathrm{B}=\mathrm{-}$ $.904, \mathrm{t}=-3.99, \mathrm{p}<0.001)$. This clearly shows that the novel linguistic and axiological identity components do not enter in conflict with the home culture even though it is depreciated and not identified with.

\section{Discussion}

The main result in our studies is the contrast between Polish students of French, residing in Poland and the groups of $1^{\text {st }}$ and $2^{\text {nd }}$ generation migrants residing in France and the francophone Belgium. We found French identity stronger than Polish among the university students, and Polish identity stronger than French among the migrants; particularly those of $2^{\text {nd }}$ generation. The findings may appear counterintuitive, especially for the Romanesque university students, whose French proficiency was at much lower level than Polish mother language, and much below French proficiency among $2^{\text {nd }}$ generation immigrants residing in France or Belgium. These surprising results may be paraphrased as: "the grass is always greener on the other side of the fence", or "I belong to the place located far away from here". But referring to adages is not enough to explain the findings. Here we have two theoretical perspectives which may do the job.

First, Weinreich and Saunderson (2005) propose a distinction between realistic and idealistic identity. The latter occurs when a person is not in daily contact with a culture of her/his choice but creates its image of a promised-land. We found evidence for such imagery identity among repatriates from Kazakhstan and also with Polish two generation 
immigrant families in Germany (Boski 2021, ch.13). Not far from this reference is a more recent theory of nostalgia (Sedikides, et al, 2009; Wildshut, et al. 2006). These authors define nostalgia as a positive, sentimental longing over the past which provides a shield/shelter over acculturative stress. We do not have direct data on nostalgia, yet the mechanism seems plausible for both categories of our participants. Thus, Romanesque students in Poland feel nostalgic after their idealized France; and Polish immigrants in France dream Poland, back home, similarly to what our great poets of XIX century did.

These results generate new questions on the issue of foreign language learning in Europe, from where we started this paper. In light of our empirical results this new question should be framed as follows: What are the desirable and not desirable effects of second language acquisition on learners cultural identities? Does our intention do modify them? replace? or leave intact? We are sure, such questions were not addressed before, because languages and linguistic competences were conceived as separate form cultural identities. Now we know, that such assumption is erroneous. Languages shape identities, and are shaped by them recursively. What may accompany or even stimulate foreign language learning is an idealized image of cultures they represent. If this happens, then the learning process becomes a way of separating oneself from the country of origin. This is perhaps what the educators would like to avoid.

\section{Conclusions}

Extension or broadening of identity is something what we consider as positive in individual development, but not identity replacement. Our forefathers resisted a forceful Germanization or Russification; but possibly they were ready for Francophilia as a better version of life. Both extremes are similar in their one-sidedness. The great European project of developing multilingualism should avoid such extremes. Languages are keys that open doors to different culture rooms. People may have preferences for some rooms more than for others but each has its own qualities which deserve to be protected and maintained. We have psychological enrichment when a person savors life entering various rooms with the linguistic keys that she/he has mastered. Being congested in one room gives a feeling of suffocation which is maldaptive.

We may finish our paper with a famous quote from Ruth Benedict (1934/2005) herself reporting a legend accounted for by chief Ramon, of the Digging Indians: 'In the beginning,' he said, 'God gave to every people a cup, a cup of clay, and from this cup they drank their life.' 'They all dipped in the water,' he continued, 'but their cups were different. Our cup is broken now. It has passed away.'

To this tragic end, the authors wish to add a more optimistic accomplishment: Today, as we belong to more than one culture at once, we should seek opportunities to drink the water of life from different cups without breaking any of them. 


\section{References}

Benedict, R. (2005). Patterns of Culture. Houghton Mifflin Harcourt.

Benet-Martínez, V., \& Haritatos, J. (2005). Bicultural Identity Integration (BII): Components and Psychosocial Antecedents. Journal of Personality, 73(4), 1015-1050.

https://doi.org/10.1111/j.1467-

6494.2005.00337.x

Benet-Martínez, V., \& Hong, Y. (2014).

The Oxford Handbook of

Multicultural Identity. Oxford

University Press.

Benet-Martínez, V., Leu, J., Lee, F., \&

Morris, M. W. (2002). Negotiating Biculturalism Cultural Frame Switching in Biculturals with Oppositional Versus Compatible Cultural Identities. Journal of CrossCultural Psychology, 33(5), 492-516. https://doi.org/10.1177/00220221020 33005005

Bennett, J. M., \& Bennett, M. J. (2004).

Developing Intercultural Sensitivity: An Integrative Approach to Global and Domestic Diversity. In D. Landis, J. M. Bennett, \& M. J. Bennett (Eds.), Handbook of Intercultural Training (3rd ed., pp. 147-165). SAGE Publications, Inc. https://doi.org/10.4135/97814522311 29

Bialystok, E. (1999). Cognitive Complexity and Attentional Control in the Bilingual Mind. Child Development, 70(3), 636-644. https://doi.org/10.1111/14678624.00046

Bialystok, E. (2011). Reshaping the Mind: The Benefits of Bilingualism. Canadian Journal of Experimental Psychology = Revue Canadienne de Psychologie Experimentale, 65 (4),
229-235.

https://doi.org/10.1037/a0025406

Boski, P. (2006). Humanism-materialism centuries -long polish cultural origins and 20 years of research in cultural psychology. In U. Kim, K.-S. Yang, \& K.-K. Hwang, Indigenious and Cultural Psychology. NY: Springer.

Boski, P. (2021). Kulturowe ramy zachowań społecznych: Podręcznik psychologii międzykulturowej (2nd ed.). Wydawnictwo Naukowe PWN; Academica Wydawnictwo SWPS.

Boski, P., Kmiotek, Ł. (2021). Acculturation as a Learning Process of Bilingual Competences and Bicultural Identity Acquisition. International Journal of Psychology (under rewview).

Cenoz, J., Genesee, F., \& Gorter, D. (2013). Critical Analysis of CLIL: Taking Stock and Looking Forward. Applied Linguistics, 1-21. https://doi.org/10.1093/applin/amt01

Crystal, D. (2003). English as a Global Language. Cambridge University Press.

http://ebooks.cambridge.org/ref/id/C BO9780511486999

Delvin, K. (2015). Learning a foreign language a 'must' in Europe, not so in America. Pew Research Center. https://www.pewresearch.org/facttank/2015/07/13/learning-a-foreignlanguage-a-must-in-europe-not-so-inamerica/

Emmorey, K., Luk, G., Pyers, J. E., \& Bialystok, E. (2008). The Source of Enhanced Cognitive Control in Bilinguals. Psychological Science, 19(12), 1201-1206. https://doi.org/10.1111/j.14679280.2008.02224.x

Grosjean, F. (2010). Bilingual: Life and reality. Harvard University Press. 
Grosjean, F. (2015). Bicultural bilinguals. International Journal of Bilingualism, 19(5), $572-586$. https://doi.org/10.1177/13670069145 26297

Hamers, J. F., \& Blanc, M. (2000). Bilinguality and Bilingualism. Cambridge University Press.

Hong, Y., Morris, M. W., Chiu, C., \& Benet-Martínez, V. (2000). Multicultural minds: A dynamic constructivist approach to culture and cognition. American Psychologist, 55(7), 709-720.

https://doi.org/10.1037/0003066X.55.7.709

Hurtado, Aída. (2016). The Social Psychology of Spanish/English Bilingualism in the United States. In M. Gelfand, C. Chiu, \& Y. Hong (Eds.), Handbook of Advances in Culture and Psychology (Vol. 6). Oxford University Press. http://www.oxfordscholarship.com/vi ew/10.1093/acprof:oso/97801904588 50.001.0001/acprof-9780190458850chapter-4

Hurtado, Aida, \& Gurin, P. (1987). Ethnic Identity and Bilingualism Attitudes. Hispanic Journal of Behavioral Sciences, 9(1), 1-18. https://doi.org/10.1177/07399863870 3090101

Kmiotek, Ł. K. (2020). Polsko-francuska dwujęzyczność $i$ dwukulturowa tożsamość: Badania $z$ udziatem polskich emigrantów w krajach frankofonskich i studentach filologii romańskiej w Polsce. [Polish-French bilingualism and bicultural identity. Studies on Polish immigrants in France and Belgium, and French language students in Poland.] [Unpublished PhD thesis]. SWPS.
La Fromboise, T., Coleman, H. L., \& Gerton, J. (1993). Psychological impact of biculturalism: Evidence and theory. Psychological Bulletin, 114(3), 395-412. https://doi.org/10.1037/00332909.114.3.395

Lapresta-Rey, C., \& Huguet, D. Á. (2019). Multilingualism in European Language Education. Multilingual Matters.

Mohanty, A., \& Perregaux, C. (1997). Language acquisition and bilingualism. In Handbook of CrossCultural Psychology. Alladyn and Bacon.

Schönpflug, U. (2008). Cultural Transmission: Psychological, Developmental, Social, and Methodological Aspects. Cambridge University Press.

Sedikides, C., Wildschut, T., Routledge, C., Arndt, J., Zhou, X. (2009). Buffering acculturative stress and facilitating cultural adaptation. Nostalgia as a psychological resource. In R. S. Wyer, C.-y. Chiu, \& Y.-y. Hong (Eds.), Understanding culture: Theory, research, and application (p. 361-378). Psychology Press.

Smolicz. (1981). Core values and cultural identity. Ethnic \& Racial Studies, 4(1), 75.

Tadmor, C., Chao, M., Hong, Y. Y., \& Polzer, J. (2012). Not Just for Stereotyping Anymore: Racial Essentialism Reduces DomainGeneral Creativity. Psychological Science, 24. https://doi.org/10.1177/09567976124 52570

Tadmor, C. T., Satterstrom, P., Jang, S., \& Polzer, J. T. (2012). Beyond Individual Creativity: The 
Superadditive Benefits of Wierzbicka, A. (1997). Understanding Multicultural Experience for Cultures through Their Key Words: Collective Creativity in Culturally English, Russian, Polish, German, Diverse Teams. Journal of Cross- and Japanese. Oxford University Cultural Psychology, 43(3), 384-392. https://doi.org/10.1177/002202211 1435259.

Weinreich, P., \& Saunderson, W. (2005). Analysing Identity: Cross-Cultural, Societal and Clinical Contexts. Routledge.

Weretiuk, O. (2006). FILOZOFIA PORAŻKI: BERESTECZKO LINY KOSTENKO. Press.

Wierzbicka, A. (1999). Język, umyst, kultura. Wrszawa: Wydawn. Nauk. PWN.

Wildschut, T., Sedikides, C., Arndt, J., \& Routledge, C. (2006). Nostalgia: Content, triggers, functions. Journal of Personality and Social Psychology, 91(5), 975-993. https://doi.org/10.1037/00223514.91.5.975. 